\title{
Wavelength-dependent induction of thymine dimers and growth rate reduction in the marine diatom Cyclotella sp. exposed to ultraviolet radiation
}

\author{
A. G. J. Buma*, A. H. Engelen, W. W. C. Gieskes \\ Department of Marine Biology, University of Groningen, PO Box 14, 9750 AA Haren, The Netherlands
}

\begin{abstract}
Cultures of the marine diatom Cyclotella sp. were subjected to vanous polychromatic exposures of UVB radiation (280-320 nm), UVA radiation (320-400 nm) and photosynthetically active radiation, PAR $(400-700 \mathrm{~nm})$. Changes in growth rate and residual thymine dimer content (a measure for DNA damage) were measured during prolonged exposure (6 to 7 d) to these conditions. Also, changes in mean cell size were studied as an indication of UV radiation induced cell cycle arrest in Cyclotella sp. Growth rate reduction was strongly related with residual thymine dimer content in treatments including wavelengths below $302 \mathrm{~nm}$. Additionally, sıgnificant increases in mean cell size were found in these cultures. This suggests that UVB-induced residual DNA damage is followed by cell cycle arrest and growth rate reduction in Cyclotella sp. We discuss how these results can be interpreted in relation to changes in the solar spectrum as a result of stratospheric ozone reduction.
\end{abstract}

KEY WORDS: Marine diatom - Polychromatic UVR exposures DNA damage - Thymine dimers Growth - Wavelength-dependent effects

\section{INTRODUCTION}

Decreased stratospheric ozone concentrations result in increases in UVB radiation (UVBR: 280-320 nm) (Madronich 1995). In contrast, ozone depletion will have virtually no effect on surface UVA radiation (UVAR: $320-400 \mathrm{~nm}$ ). Since ozone absorbs shorter UVB wavelengths more efficiently than longer ones, ozone concentration not only determines total UVR, but also the spectral composition within the UVBR band. Progressively more of the shorter UVBR wavelengths will reach the earth's surface as stratospheric ozone is reduced. Since shorter wavelengths cause greater biological damage than longer ones (Caldwell et al. 1986), ozone depletion causes the atmosphere to become more translucent to biologically highly active radiation.

\footnotetext{
·E-maul: a.g.j.buma@biol.rug.nl
}

UV radiation can penetrate well into the euphotic zone in marine waters (Smith \& Baker 1979, Gieskes \& Kraay 1990, Karentz \& Lutze 1990. Smith et al. 1992). Thus, primary producers may be affected by UVR, even without ozone depletion (Worrest 1983, Helbling et al. 1992). UVR affects phytoplankton productivity (Worrest 1983), growth (Jokiel \& York 1984, Behrenfeld et al. 1992), photosynthesis (El-Sayed et al. 1990, Cullen \& Lesser 1991, Helbling et al. 1992, Lesser et al. 1994), photosynthetic pigments (Worrest et al. 1978 . El-Sayed et al. 1990), cell size (Karentz et al. 1991, Behrenfeld et al. 1992, Buma et al. 1996b), nutrient uptake (Behrenfeld et al. 1995), amino acid synthesis (Goes et al. 1995), orientation and motility (Häder 1993). Both UVAR and UVBR can cause cell death and mutation or other forms of DNA damage (Coohill \& Deering 1969. Karentz et al. 1991, Buma et al. 1995. 1996a). The mechanisms inducing DNA damage in the UVAR region of the spectrum are poorly understood. It is unlikely that UVAR is directly absorbed by DNA. 
Consequently it is assumed that there is an indirect photodynamic type of reaction involved such as radical formation (Peak \& Peak 1983). For UVBR a direct reaction is conceivable, as UVBR is absorbed by DNA and proteins. A typical effect of UVBR is the dimerization of DNA thymine bases, which may cause problems in cell division, due to the interference with DNA synthesis (Britt 1995). There are several ways in which DNA damage can be repaired, one of which is photoreactivation (reviewed by Sancar \& Sancar 1988). This repair is known to be brought about by light with wavelengths between 330 and $450 \mathrm{~nm}$ (Sancar \& Sancar 1988). Little is known about synergistic or antagonistic effects of the various wavelengths, for instance how they interact in the full spectrum of natural radiation (Coohill 1991).

In order to be able to understand the impact of ozone-related increases in UVBR on marine microalgae, experimental data on the biological significance of UVBR, UVAR and photosynthetically active radiation (PAR; $400-700 \mathrm{~nm}$ ) as well as their interactions are needed. Also, relevant UVR action spectra for biological key processes such as photosynthesis, growth or DNA damage need to be determined. Biological action spectra may serve several purposes: first of all they serve as spectral weighting functions that are used to determine whether a change in UVR is biologically significant. Secondly, application of action spectra is essential in the device of experimental UV effect studies. Finally, action spectra are necessary for the assessment of the attenuation of biologically effective UVR in water, since the underwater UV spectrum is strongly influenced by physio-chemical factors. Some action spectra determined for plants have been constructed using monochromatic light (Halldal 1964, Jones \& Kok 1966, Hashimoto et al. 1991, Quaite et al. 1992). The most common action spectra used to assess biological effects in relation to ozone trends are the plant action spectrum of Caldwell (1971), derived from general damage to terrestrial plants, and the DNA action spectrum of Setlow (1974), derived from the occurrence of photoproducts in DNA and phages.

Precise analytical action spectra are difficult to obtain when whole organisms are investigated or when polychromatic light is used (Coohill 1991). However, the application of polychromatic radiation allows the incorporation of interactions of biological responses to different wavelengths and may thereby be ecologically more relevant, even when the primary target involved in the manifestation of UV-stress cannot be determined (Rundel 1983, Caldwell et al. 1986, Coohill 1991, 1992). Additionally, there is an urgent need for specific phytoplankton action spectra focussing on relevant UVR target processes. Recently, several action spectra have been described express- ing UVR effects on phytoplankton photosynthesis (Cullen et al. 1992, Helbling et al. 1992, Behrenfeld et al. 1993) and ammonium uptake (Behrenfeld et al. 1995).

There are important conditions for action spectrum construction, which are not always met (Coohill 1991). Two of these conditions are that reciprocity between UV dose rate and UV exposure time must hold and that identical dose-response relationships should exist for each wavelength condition. If the latter is not the case, then the action spectrum will change in shape when the energy or photon fluence level of the light is modified. In an effort to construct a polychromatic action spectrum for UVR-induced growth inhibition in Cyclotella sp. we were faced with the problem of different, non-linear dose-response patterns at the various polychromatic wavelength conditions applied. Non-linear dose response relationships are found more often (Setlow et al. 1993) although linear relationships have also been described under polychromatic conditions (Caldwell et al. 1986).

In our study we applied a single energy level of PAR and UVR with varying relative amounts of UVBR and UVAR. In this way, spectral composition was the only variable in the various UV treatments. For this reason the wavelength-dependent changes for DNA damage (residual thymine dimer content), growth inhibition and cell size as presented in this study are not meant to be interpreted as action spectra. This study was merely meant to correlate wavelength-dependent changes for various parameters. Growth rate reduction was chosen because this parameter is expected to be the integrating resultant of all possible mitigating processes in phytoplankton cells, providing direct information of the impact of UVR on phytoplankton. Thymine dimer formation was chosen as an indication of DNA damage, with the aim of obtaining information on the role of DNA dimer abundance in UVBR-induced growth reduction. Since in our study polychromatic exposures were used, including UVAR and PAR, photoreactivation may have counteracted the formation of thymine dimers. Therefore the thymine dimers which were detected may be considered as the residual amount of dimers, taking into account repair processes. Additionally, data were collected to study wavelength-related changes in cell size as a signal for UVR-mediated effects on the cell cycle.

\section{MATERIALS AND METHODS}

The diatom Cyclotella sp. was used as the test organism (MARBIOL culture collection). Cyclotella spp. are phytoplankton species commonly found in the North Sea. Cultures of Cyclotella sp. were maintained in a 
$14 \mathrm{~h}$ light (PAR): $10 \mathrm{~h}$ dark cycle at $16 \pm 0.5^{\circ} \mathrm{C}$. The culture vessels used for the experiments were rectangular, hand-made quartz cuvettes with a working volume of $600 \mathrm{ml}$ [Louwers Hapert, height $11.5 \mathrm{~cm}$, width $11.5 \mathrm{~cm}$, depth (light path) $5.0 \mathrm{~cm}$ ] with a teflon lid. Cultures were maintained in $\mathrm{F} / 2$ medium (Guillard 1975) using artificial sea water ( $34.5 \%$ salinity) based on Milli-Q water, enriched with V8 vitamin mixture, and the trace metal solutions Minor 1 and Minor 2 .

An experimental system was developed for measuring polychromatic wavelength-dependent UV effects. The system was designed to hold 8 quartz cuvettes, each on a stirring rotor. Temperature was controlled by an internal cooling system. UVR lamps were placed at one side of the cultures, and photosynthetically active radiation (PAR) lamps at the other. UV radiation was provided by 2 Philips TL 12 (UVBR) and 2 Philips 09 N (UVAR) lamps, which had been preburned for at least $100 \mathrm{~h}$ prior to the experiments to ensure that lamp emissions were stable (Steeneken et al. 1995). In order to obtain different spectral UVR conditions in the cultures, various Schott WG cut-off filters (Schott, WG series) were placed between the culture vessels and the UVR lamps. The Schott filters used were: WG 280-3mm thickness, WG 280-5mm, WG 295-2mm, WG 295-3mm, WG 295-4mm, WG 305-3mm, WG $320-3 \mathrm{~mm}$, WG $335-3 \mathrm{~mm}$, WG $345-3 \mathrm{~mm}$ and $W G$ 360-3mm. One culture that was shielded from the UVR lamps served as the inoculation culture for the experimental series (no UVR). In this way each series consisted of 7 different UV-treated samples and 1 control culture

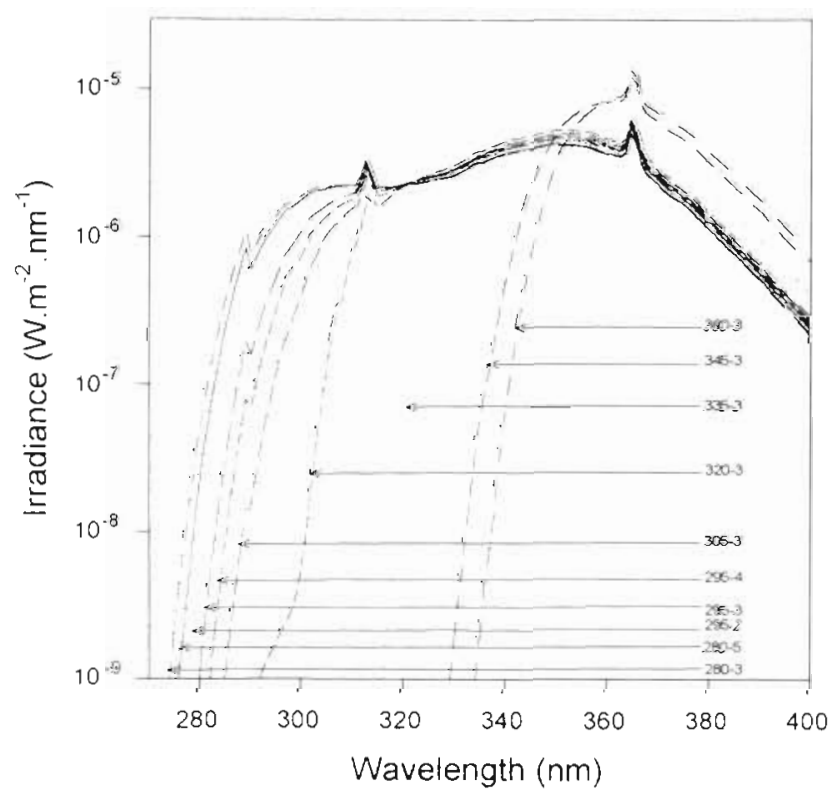

Fig. 1. Spectral UVR conditions (in $W \mathrm{~m}^{-2} \mathrm{~nm}^{-1}$ ) in the cultures brought about by 2 UVAR and 2 UVBR lamps in combination with Schott WG cut-off filters. Numbers refer to the names of the filters used and their respective thicknesses (in $\mathrm{mm}$ )
(Fig. 1). For all experiments identical UVR dose rates of 167.5 ( $\mathrm{W} \mathrm{cm}^{-2}, 280-400 \mathrm{~nm}$ ) were used, measured with an Optronics spectroradiometer (model OL 752). PAR $(400-700 \mathrm{~nm})$ was supplied separately for each culture vessel by a halogen lamp (Sylvania, model Professional, $50 \mathrm{~W}, 12 \mathrm{~V}, 13^{\circ}$, diameter $50 \mathrm{~mm}$ ) for each cuvette. For each culture the distance of the PAR source was adjusted to give a mean intensity of $400 \mu \mathrm{mol} \mathrm{m} \mathrm{m}^{-2} \mathrm{~s}^{-1}$. measured as incident irradiance directly behind the quartz glass surface. At this intensity photosynthesis is maximal in Cyclotella sp. Cuvettes were inoculated with Cyclotella and grown for a period of at least $3 \mathrm{~d}$ with PAR only. During this period cells were counted daily to obtain the reference growth rate (no UVR) for each culture. Then the cultures were exposed to UVR for $3 \mathrm{~h}$ in the middle of the light (PAR) period. This treatment was repeated over 6 consecutive days. Each spectral experiment was performed in triplicate.

Cells were counted live in Sedgewick Rafter counting chambers at daily intervals. Per sample at least 500 cells were counted. Specific growth rates $(\mu)$ were calculated over the non-UV period (lag phase not included) and the UVR exposure period using linear regression analysis of semilog-transformed data. UVRinduced growth rate reduction was determined for each individual culture from the difference between these slopes. After the last UVR treatment, samples were taken for analysis of DNA damage and cell size.

At the end of each experiment 1 to $3 \mathrm{ml}$ samples were taken from each culture and fixed with formaldehyde. Cell size measurements were performed using an image analysis system (Optimas, Bioscan Inc, version 4.10) connected to an Olympus IMT-2 inverted microscope with an AIS MX5 camera. The system was calibrated with an objective micrometer With a standard magnification of 300 , the area $\left(\mu \mathrm{m}^{2}\right)$ of the longitudinal section of about 140 to 540 cells was measured in each sample. The system was programmed to discriminate between background noise, non-living particles and Cyclotella cells. For each sample, statistical parameters of the cell longitudinal section area were determined. The longitudinal cell section area was used to assess the mean cell volume. Cell volume cannot directly be calculated from the longitudinal cell section area without knowing the radius of the cells. However, diatoms grow only in the longitudinal direction during interphase, and the radius $(r)$ only decreases very slightly with cell division. Since cell volume is $1 / 2 \pi r \times$ longitudinal area, the conversion of area to cell volume is through multiplication by a constant, as long as $r$ is fixed. Therefore in our experiments the longitudinal cell section area gives a good estimate of cell volume.

After the last UVR treatment $15 \mathrm{ml}$ aliquots of culture were fixed in $1 \%$ formaldehyde, and concentrated by 
centrifugation, after which pellets were frozen in liquid nitrogen and subsequently stored at $-80^{\circ} \mathrm{C}$ until further processing. Thymine dimers (DNA damage) were measured according to a method described by Buma et al. (1995). A monoclonal antibody raised against thymine dimers ( $\mathrm{H} 3$ ) was used, in combination with a secondary antibody (FITC) for flow cytometric DNA damage detection (Buma et al. 1995). Of each culture 2 estimates of the percentage of damaged cells were made and averaged. Finally triplicate series were averaged. All results were statistically tested using a single factor analysis of variance (multisample test: ANOVA) followed by Scheffé $F$-tests to analyse sample pairs (Zar 1984).

Successive UVR spectra as received by the cultures were subtracted from each other using the method of Rundel (1983) for action spectra construction. Optimum wavelengths of these difference spectra were chosen as the wavelength against which the measured effect was plotted. These wavelengths were: $289 \mathrm{~nm}$ (Schott 280-3mm), $297 \mathrm{~nm}$ (Schott 280-5mm), $299 \mathrm{~nm}$ (Schott 295-2mm), $302 \mathrm{~nm}$ (Schott 295-3mm), $308 \mathrm{~nm}$ (Scholt 295-4mm), $313 \mathrm{rm}$ (Schott 305-3mm), $325 \mathrm{~nm}$ (Schott 320-3mm), $344 \mathrm{~nm}$ (Schott 335-3mm), $352 \mathrm{~nm}$ (Schott 345-3mm), $365 \mathrm{~nm}$ (Schott 360-3mm).

\section{RESULTS}

Growth rate reduction was most pronounced at the lowest wavelengths (Fig. 2). Data points were significantly different (ANOVA) and points below $302 \mathrm{~nm}$

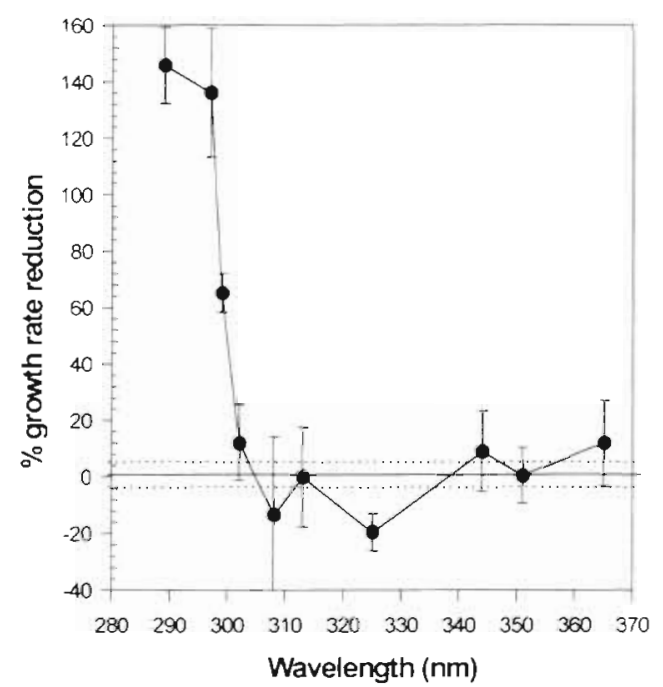

Fig 2. Cyclotella sp. Wavelength-dependent changes in growth inhibition. Vertical lines: standard deviations of the mean for different experimental series $(\mathrm{n}=3)$. Forizontal line: reference growth rate for non-UVR exposed culture. Dotted lines: standard deviation of the mean for reference growth rate

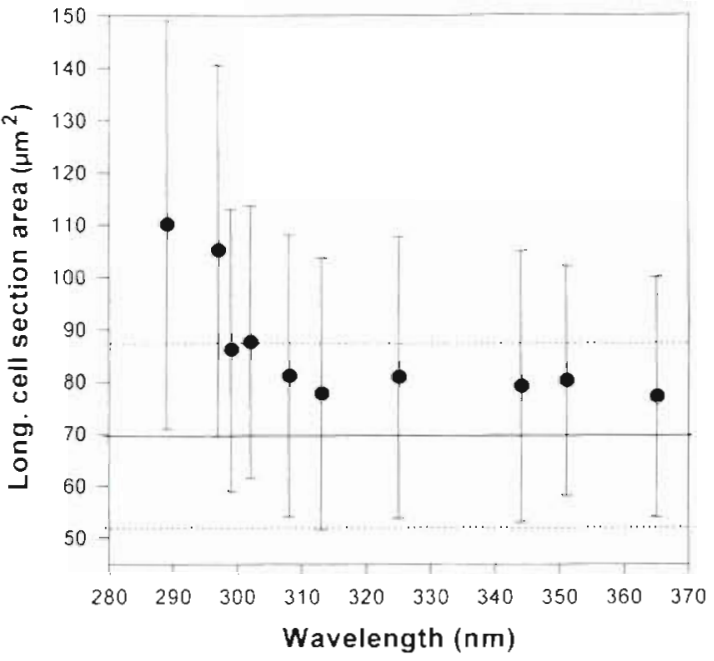

Fig. 3. Cyclotella sp. Wavelength-dependent changes in average longitudinal cell section area using image analysis. Vertical lines: population standard deviations. Horizontal line: reference longitudinal cell section area for non-UVR exposed culture. Dotted lines: population standard devlation for cell. section area in control culture

were significantly different from the control (Scheffé $F$-test, $\mathrm{p}<0.01$ ). Here, growth rate reduction showed a steep increase, exhibiting strong growth inhibition $(60 \%)$ at $299 \mathrm{~nm}$, and complete growth inhibition accompanied by cell disintegration at the lowest UVBR wavelengths. No growth inhibition was found at the highest UVBR and UVAR wavelengths. In the UVBR and UVAR bands between 313 and $345 \mathrm{~nm}$ a trend towards growth stimulation was found. However, the data points did not differ significantly from the control.

Wavelength-dependent changes in the average longitudinal cell section area of the cultures of the various experimental series showed an increase towards lower wavelengths (Fig. 3). Since in Fig. 3 a representative series is shown, the standard deviations reflect variation in cell size within the population of cells in a culture and not the variation between series. Measurements were found to be significantly different (ANOVA) and below $308 \mathrm{~nm}$ data points differed significantly from the control (Scheffé F-test, $p<0.01$ ). A cell size increase of about $23 \%$ was found when the cells were irradiated with UVAR only, independent of the wavelength used. Again, towards lower UVBR wavelengths $(280-300 \mathrm{~nm})$ the effect increased steeply.

Wavelength-related residual thymine dimer content was studied from the flow-cytometric immunofluorescence data (Fig. 4). DNA damage seemed to be present in the culture exposed to $365 \mathrm{~nm}$. Between 320 and $360 \mathrm{~nm}$ the signal was not significantly different from the control, whereas between 325 and $297 \mathrm{~nm}$ a strong increase in DNA damage was evident. 


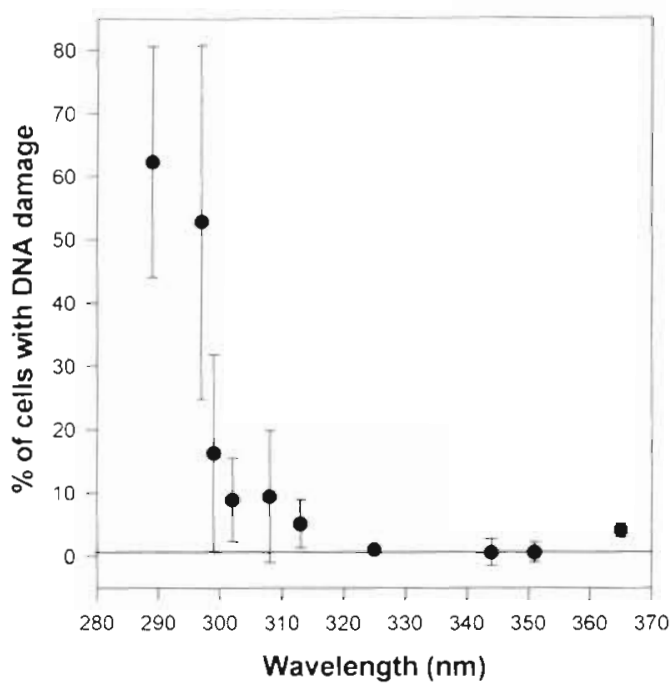

Fig. 4. Cyclotella sp. Wavelength-related changes in residual thymine dimer content constructed from flow-cytometric immunofluorescence measurements. Vertical lines: standard deviations of the mean for different experimental series $(n=3)$.

Horizontal line: reference for non-UVR exposed culture

Linear relationships were tested between the measured variables at a confidence level of $99 \%$. All tested variables were linearly related at this confidence level.

\section{DISCUSSION}

Since DNA absorbs wavelengths in the lower part of the UVBR band (absorption maximum at $260 \mathrm{~nm}$ ), the steep increase in residual thymine dimer content in this region was to be expected. Overall, thymine dimer formation in the diatom Cyclotella $\mathrm{sp}$. was mainly induced by wavelengths below $320 \mathrm{~nm}$, as found for plants (Quaite et al. 1992). The small shoulder in the UVAR band ( $365 \mathrm{~nm}$; Fig. 4) was also found by Quaite et al. (1992) and corresponds also with the shoulder found in the action spectrum for skin cancer induction (de Gruijl et al. 1993). Growth reduction was also most pronounced in the UVBR region. Therefore similarity between wavelength-dependent growth rate reduction and thymine dimer formation was high, especially in the region below $302 \mathrm{~nm}\left(\mathrm{r}^{2}=0.967\right)$. The overall similarity suggests that growth inhibition of Cyclotella sp. exposed to low UVBR wavelengths can be ascribed to thymine dimer formation in combination with insufficient repair. Since photorepair of thymine dimers is induced by wavelengths between 330 and $450 \mathrm{~nm}$, the ratio between UVBR, UVAR and PAR determines whether damage and repair are in balance. In the light of this notion growth rate reduction in the UVBR region was caused by the unbalance between thymine dimer formation and repair. At the higher wavelengths either no thymine dimers were induced, or the UVBR/ UVAR ratio, favouring the UVAR wavelengths, caused an advantageous situation favouring repair over damage.

No growth reduction was found in the UVAR region of the spectrum. As found by others (Cullen et al. 1992) natural levels of UVAR may have a net damaging effect on phytoplankton photosynthesis. The UVA irradiance level applied in this study is lower than that observed at the earth's surface and may therefore explain the discrepancy between the various results.

The cell size data support earlier findings that UVBR-induced growth inhibition is caused by DNA damage and subsequent arrest of the cell cycle in the $\mathrm{S}$ phase (Buma et al. 1996a). As common in most diatoms, cell division of Cyclotella $\mathrm{sp}$. is not phased in a population of cells subjected to a light/dark regime. This means that the population consists of cells at various stages of the cell cycle during the light period (high standard deviations in Fig. 3). As a Cyclotella cell moves through the G1 phase towards G2, cell size increases. When the majority of cells have arrived at the arrest point (i.e. S), they remain at the corresponding size until the damage is repaired. This will increase the mean cell size in the population. As shown earlier (Buma et al. 1996b), due to this cell cycle arrest, some structural components, such as pigments and protein, show increases per cell. This was also found in our experiments: incidental HPLC analysis of pigments showed increases in cellular chlorophylls, carotenoids and photoprotective pigments (diadinoxanthin + diatoxanthin) at the shortest UVBR wavelengths (not shown). Total dissolved protein was also higher in UVBR-exposed cultures compared to the controls.

Our data show that when lamp systems are used for biological effect studies, the use of adequate cut-off filters is essential. Any lamp-filter combination which permits transmission of wavelengths below $285 \mathrm{~nm}$ may cause effects (i.e. DNA damage and related effects) which are ecologically not relevant. Therefore we propose the application of Schott WG filters with. number 305 or higher (Fig. 1).

The wavelength relationships presented here should not be interpreted as biological weighting functions. However, we have related our results with the widely used DNA damage action spectrum of Setlow (1974) (Fig. 5). To this end, all spectral conditions in the culture series were multiplied by the action spectrum of Setlow, in order to obtain the biologically weighted irradiance for each culture (Setlow, normalised at $300 \mathrm{~nm}$ ). Next, these weighted daily doses were plotted against the measured data (Fig. 5). Since according to Setlow's action spectrum the short UVBR wavelengths are the most effective, these wavelengths are 


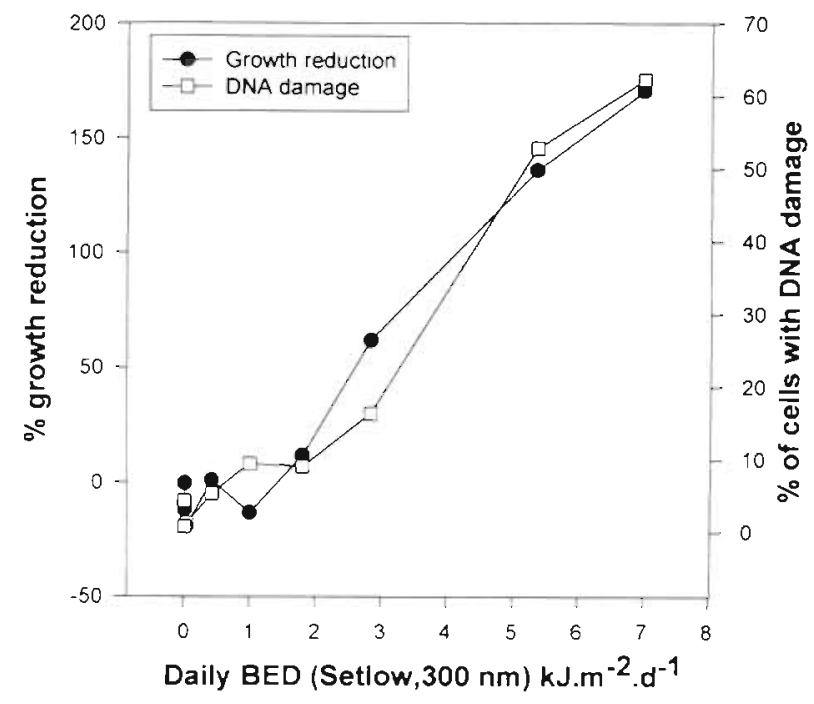

Fig. 5. Cyclotella sp. Relation between growth rate reduction, residual DNA damage and the spectral compositions of the irradiance, weighted with the action spectrum of Setlow (1974), normalised at $300 \mathrm{~nm}$ (Biological Effective Dose: BED)

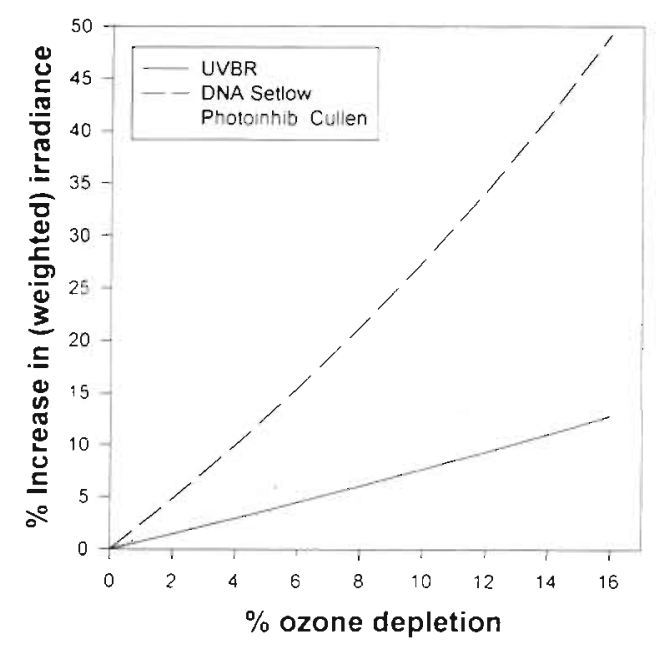

Fig. 6. Model calculation of the proportionai increases of weighted and unweighted UVBR for various degrees of ozone depletion in surface waters of the North Sea $\left(53^{\circ} \mathrm{N}, 3^{\circ} \mathrm{E}\right)$ at local noon, June 21. Spectra were calculated with a model according to Bjorn \& Murphy (1985) and weighted with the DNA action spectrum of Setlow (1974) and the photoinhibition action spectrum of Cullen et al. (1992)

represented by the highest weighted doses in Fig. 5, whereas the UVAR wavelengths are represented by the lowest weighted irradiances in Fig. 5. Although the number of data points is limited, the relationship between growth rate reduction, residual thymine dimer content and weighted doses is acceptable. However, both relationships are nonlinear, as they tend to be steeper towards higher weighted doses. This nonlinearity may be explained by the fact that the action spectrum of Setlow was composed using monochromatic light exposures, whereas in our experiments damage and repair may have interacted, especially at the lower doses (low UVBR, high UVAR). Assuming that polychromatic action spectra for residual thymine dimer content and growth rate reduction show an increase in the UVBR band as steep as that of the Setlow (1974) action spectrum, then stratospheric ozone reduction will have a large relative impact on the risk of DNA damage in marine phytoplankton, and thereby for growth rate reduction, more than the effect on photoinhibition (Cullen et al. 1992). This is illustrated in Fig. 6, where for one location at the surface of the North Sea $\left(53^{\circ} \mathrm{N}, 3^{\circ} \mathrm{E}\right)$, relative increases in biologically effective irradiance were calculated for various levels of ozone depletion. The action spectra used here are the DNA action spectrum of Setlow (1974) and the photoinhibition action spectrum of Cullen et al. (1992). whereas the irradiance spectra for the various ozone depletions scenarios were calculated according to a model of Björn \& Murphy (1985). Even though the absolute impact of DNA damage and photoinhibition. cannot be derived from this model - this depends on the absolute values of effectiveness in each action spectrum-the relative impact of DNA damage is much higher than that of photoinhibition. For example, a $16 \%$ ozone reduction would bring about a $12.7 \%$ increase in unweighted UVBR, and a $19.9 \%$ and $49.3 \%$ increase in weighted irradiance weighted with the action spectra of respectively Cullen et al. (1992) and Setlow (1974). In conclusion, in phytoplankton populations where the conditions for the occurrence of DNA damage are favourable, even a small shift in the UVBR range of the solar spectrum towards shorter wavelengths, resulting from ozone depletion, may bring about large changes in biologically effective dose rates reaching marine waters and therefore will substantially increase the risk for organisms to be subjected to growth rate reduction or mortality as resulting from DNA damage.

Acknowledgements. The authors thank Marcel. J W. VeIdhuis and Peter Boelen for technical assistance. This project was partly financed by the Dutch NRP program on Climate Change Research (project number 851054 ) and partly by the Commission of Antarctic Research of GOA (project number 750.495.04).

\section{LITERATURE CITED}

Behrenfeld MJ, Chapman JW, Hardy JT, Lee H II (1993) Is there a common response to ultraviolet- $B$ radiation by marine phytoplankton? Mar Ecol Prog Ser 102:59-68

Behrenfeld MJ, Hardy JT, Lee H II (1992) Chronic effects of ultraviolet-B radiation on growth and cell volume of 
Phaeodactylum tricornutum (Bacillariophyceae). J Phycol 28:757-760

Behrenfeld MJ, Lean DRS, Lee H II (1995) Ultraviolet-B radiation effects on inorganic nitrogen uptake by natural assemblages of oceanic phytoplankton. J Phycol 31:25-36

Bjorn LO, Murphy TM (1985) Computer calculation of solar ultraviolet radiation at ground level. Physiol Veg 23(5): $555-561$

Britt $A B$ (1995) Repair of DNA damage induced by ultraviolet radiation. Plant Physiol 108:891-896

Buma AGJ, van Hannen EJ, Veldhuis MJW, Gieskes WWC (1996a) UV-B induces DNA damage and DNA synthesis delay in the marine diatom Cyclotella sp. Sci Mar 60:101-106

Bumu AGJ, van Hannen EJ, Veldhuis MJW, Roza L, Gieskes WWC (1995) Monitoring UV-B induced DNA damage in individual diatom cells by immunofluorescent thymine dimer detection. J Phycol 31:314-321

Buma AGiJ, Zemmelink HJ, Sjollema K, Gieskes WWC (1996b) UVB radiation modifies protein and photosynthetic pigment content, volume and ultrastructure of marine diatoms. Mar Ecol Prog Ser 142:47-54

Caldwell MM (1971) Solar UV irradiation and the growth and development of higher plants. In: Giese AC (ed) Photophysiology, Vol 6. Academic Press, New York, p 131

( ildwell MM1 Camp LB, Warner CW, Flint SD (1986) Actionspectra and their key role in assessing biological consequences of solar UV-B radiation change. In: Worrest RC, Caldwell MM (eds) Stratospheric ozone reduction, solar ultraviolet radiation and plant life. NATO ASI Series, Vol G8. Sprunger-Verlag, Berlin, p 87-107

Coolill TP (1991) Action spectra again? Photochem Photobiol $54(5): 859-870$

Coohill TP (1992) Action spectra revisited. Photochem Photobiol 13:95-100

Coohill TP, Deering RA (1969) Ultraviolet light inactıvation of Blastocladiella emersonil. Radiat Res 39:374-385

Cullen JJ, Lesser MP (1991) Inhıbition of photosynthesis by ultraviolet radiation as a function of dose and dosage rate: results for a marine diatom. Mar Biol 111:183-190

Cullen JJ, Neale PJ, Lesser MP (1992) Biological weighting function for the inhibition of phytoplankton photosynthesis by ultraviolet radiation. Science 258:646-650

de Gruijl FR, Sterrenborg HJCM, Forbes PD, Davies RE, Cole C, Kelfkens $G$, van Weelden H, Slaper $H$, van der Leun JC (1993) Wavelength dependence of skin cancer induction by ultraviolet irradiation of albino hairless mice. Cancer Res 53:53-60

El-Sayed SZ, Stephens FC, Bidigare RR, Ondrusek ME (1990) Effect of ultraviolet radiation on Antarctic marine phytoplankton. In: Kerry KR, Hempel G (eds) Antarctic ecosystems. Ecological change and conservation. SpringerVerlag, Berlin, p 379-385

Gieskes WWC, Kraay GW (1990) Transmission of ultraviolet light in the Weddell Sea: report on the first measurements made in Antarctic. Biomass Newsl 12:12-14

Goes JI, Handa N, Taguchı S, Hama T, Saito H (1995) Impact of UV radiation on the production patterns and composition of dissolved free and combined amino acids in marine phytoplankton. J Plankton Res 17(6):1337-1362

Guillard RRL (1975) Culture of phytoplankton for feeding marine invertebrates. [n: Smith WL, Chanley $\mathrm{MH}$ (eds) Culture of marine invertebrate animals. Plenum Publishing Corp, New York, p 29-60

Hader D (1993) Risks of enhanced solar ultraviolet radiation for aquatic ecosystems. Prog Phycol Res 9:1-32
Halldal P (1964) Ultraviolet action spectra of photosynthesis and photosynthetic unhibition in a green and red alga. Physiol Plant 17:414-421

Hashimoto I, Shichijo C, Yatsuhashi H (1991) Ultraviolet action spectra for the induction and inhibition of anthocyanin synthesis in broom sorghum seedlings. J Photochem Photobiol B Biol 1 1:353-363

Helbling EW, Villafane V, Ferrario M, Holm-Hansen O (1992) Impact of natural ultraviolet radiation on rates of photosynthesis and on specific marine phytoplankton species. Mar Ecol Prog Ser 80:89-100

Jokiel PL, York RH Jr (1984) Importance of ultraviolet radiation in photoinhibition of marine algae. Limnol Oceanogr 29:192-199

Jones LW, Kok (1966) Photoinhibition of chloroplast reactıons. I. Kinetics and action spectra. Plant Physiol 41: $1037-1043$

Karentz D, Cleaver JE, Mitchell DL (1991) Cell survival characteristics and molecular responses of Antarctic phytoplankton to ultraviolet-B radiation. J Phycol 27:326-341

Karentz D, Lutze LH (1990) Evaluation of biological harmful ultraviolet radiation in Antarctica with a biological dosimeter designed for aquatic enviroments. Limnol Oceanogr 35:245-257

Lesser MP, Cullen JJ, Neale PJ (1994) Carbon uptake in a marine diatom during acute exposure to ultraviolet $B$ radiation: relative importance of damage and repair. J Phycol 30:183-192

Madronich S (1995) The radiation equation. Nature 377:682

Peak MJ, Peak JG (1983) Use of action spectra for Identifying molecular targets and mechanisms of action of solar ultraviolet light. Physiol Plant 58:367-372

Quaite FE, Sutherland BM, Sutherland JC (1992) Action spectrum for DNA damage in alfalfa lowers predicted impact of ozone depletion. Nature 358:576-578

Rundel RD (1983) Action spectra and estimation of biologically effective UV raduation. Physiol Plant 58:360-366

Sancar A, Sancar GB (1988) DNA repair enzymes. Annu Rev Biochem 57:29-67

Setlow RB (1974) The wavelength in sunlight effective in producing skin cancer: a theoretical analysis. Proc Natl Acad Sci USA 71(9):3363-3366

Setlow RB, Grist E, Thompson K, Woodhead AD (1993) Wavelengths effective in induction of malignant melanoma. Proc Natl Acad Sci USA 90:6666-6670

Smith RC, Baker KS (1979) Penetration of UV-B and biologically effective dose-rates in natural waters. Photochem Photobiol 29:311-323

Smith RC, Prezelin BB. Baker KS, Bidigare RR, Boucher NP, Coley T, Karentz D, MacIntyre S, Matlick HA, Meñzies D. Ondrusek M, Wan Z, Waters KJ (1992) Ozone depletion: ultraviolet radiation and phytoplankton biology in Antarctic waters. Science 255:952-959

Steeneken SF, Buma AGJ, Gieskes WWC (1995) Changes in transmission characteristics of polymethylmethacrylate and cellulose (III) acetate during exposure to ultraviolet light. Photochem Photobiol 61(3):276-280

Worrest RC (1983) Impact of solar ultraviolet-B radiation (290-320 nm) upon marine microalgae. Physıl Plant 58: $428-434$

Worrest RC, van Dyke $H$, Thomson BE (1978) Impact of enhanced simulated solar ultraviolet radiation upon a marne community. Photochem Photobiol 27:471-478

Zar JH (1984) Biostatustical analysis. Prentice Hall, Englewood Cliffs, NJ

Manuscnpt first received: November 12,1996

Revised version accepted: May 22, 1997 